\title{
Comparative Analysis of Hydrogenotrophic Denitrification in up and down Flow Reactors
}

\author{
Rabin Maharjan', Iswar Man Amatya ${ }^{1 a}$, Ram Kumar Sharma ${ }^{2}$ \\ ${ }^{1}$ Department of Civil Engineering, Pulchowk Campus, Institute of Engineering, TU, Nepal \\ ${ }^{2}$ Department of Applied Sciences, Pulchowk Campus, Institute of Engineering, TU, Nepal \\ ${ }^{a}$ Corresponding author: iswar@ioe.edu.np
}

Received: Dec 13, 2018

Revised: Feb 28, 2019

Accepted: March 3, 2019

\begin{abstract}
Use of ground water containing ammonical nitrogen has been increasing in Kathmandu valley. The use of locally and cheaply fitted Hydrogenotrophic Denitrification (HD) has been taken as an effective way to remove the nitrates in this study. Comparative analysis of HD reactors had been studied for the determination of the effective flow direction of water as Up Flow or Down Flow. The result reviled that flow direction as Down Flow HD reactor performed slightly better than Up Flow HD reactor. The maximum $\mathrm{NO}_{3}-\mathrm{N}$ conversion reached $100 \%$ for Down Flow and $98.65 \%$ for Up Flow reactor with maximum of total inorganic nitrogen (TIN) removed were $41.11 \%$ and $33.89 \%$ for Down Flow and Up Flow reactor respectively. The difference in $\mathrm{NO}_{3}-\mathrm{N}$ conversion and TIN removal were observed. As the $\mathrm{NO}_{2}-\mathrm{N}$ was accumulated, suggesting $\mathrm{NO}_{3}$ conversion is higher than $\mathrm{NO}_{2}$ conversion thus, and majorly incomplete denitrification existed. The $\mathrm{NO}_{2}-\mathrm{N}$ in water reached to maximum of $78.89 \mathrm{mg} / \mathrm{l}$ and $72.55 \mathrm{mg} / \mathrm{l}$ for Down Flow and Up Flow rector.
\end{abstract}

Keyword: Hydrogenotrophic denitrification, flow direction, nitrate, nitrite, nitrite accumulations

\section{Introduction}

With the rise in population in Kathmandu valley, the demand for the water is ever growing. The demand has been higher than the water that can be supplied by the responsible organization Kathmandu Upatyaka Khanepani Limited (KUKL). So dependent in other sources had been increasing. Ground water source has come up as the way of fulfilling the demand. The use of ground water has been done for domestic purpose, industrial and other uses. The contaminants in water have also raised some issues directly or indirectly. Among such contaminants, nitrogen is one of it, which cannot be removed easily. Majorly in ground water, nitrogen is found as ammonia-N or its oxidized state as nitrate-N. As per Chapagain and Kazama, Kathmandu valley has the highest concentration of $119.8 \mathrm{mg} / \mathrm{l}$ and generally average of about $23.3 \mathrm{mg} / \mathrm{l}$ of $\mathrm{NH}_{4}-\mathrm{N}$ in deep wells [1].

The ammonia nitrification process helps to oxidize the ammonia to the nitrate by nitrifying bacteria in presence of oxygen. Thus formed nitrate remains in water. Complete nitrogen removal occurs only when the nitrates are converted to nitrogen gas and is separated easily. The conversion of nitrate is done by the denitrification process where the nitrate is reduced to nitrogen gas through 
its unstable intermediate states. Denitrifying bacteria will consume the oxygen in nitrate in an aerobic condition. The HD exists in presence of hydrogen as an electron donor. The supply of $\mathrm{H}_{2}$ gas helps to keep the anaerobic condition and availability of electron donor. HD bacteria are chemolitho-autotrops so it takes carbon from inorganic sources like bicarbonates, carbonates or carbon dioxide. The main advantages of HD reactors is its high efficiency and no harmful or objectionable byproducts. The resulting hydrogenated water has additional health benefits for reducing reactive oxygen metabolites in blood and maintaining blood oxidation potential and also helps to reduce biological reaction to radiation induced oxidative stress without compromising antitumor effects for cancer patients [5]. Disadvantages are solely represented by the combustibility risks and economy of hydrogen gas.

$\mathrm{NO}_{3}^{-}+\mathrm{H}^{+}+2.86 \mathrm{H}_{2}+0.15 \mathrm{CO}_{2} \rightarrow 0.0286 \mathrm{C}_{5} \mathrm{H}_{7} \mathrm{NO}_{2}+0.49 \mathrm{~N} 2+3.14 \mathrm{H}_{2} \mathrm{O}$

From equation (1), $0.41 \mathrm{gm}$ of Hydrogen gas is required to reduce $1 \mathrm{gm}$ of Nitrate to Nitrogen gas, while the reduction of Nitrite to Nitrogen gas generates $3.57 \mathrm{~g}$ of alkalinity as $\mathrm{CaCO}_{3}$ per $1 \mathrm{~g}$ $\mathrm{NO}_{3}-\mathrm{N}$ reduced [4].

\section{Methods and Materials}

\subsection{Influent Preparation}

Influent water with nitrate was prepared from the ground water containing ammonia- $\mathrm{N}$ of Pulchowk Campus, Institute of Engineering (IOE), Pulchowk, Nepal. Ammonical-N was oxidized to nitrate-N via nitrification process from dripping nitrification system located at north of Girls' Hostel of IOE. As the study is conducted in field, the concentrations of nitrates in influent varied throughout the study period.

\subsection{Experimental Setup}

Two HD reactors were constructed using the concept of locally available materials, PVC pipe of $14 \mathrm{~cm}$ internal diameter and height of $225 \mathrm{~cm}$ with one end closed was taken as reactor with inlet and outlet at top and bottom of reactor with working water level up to $220 \mathrm{~cm}$.

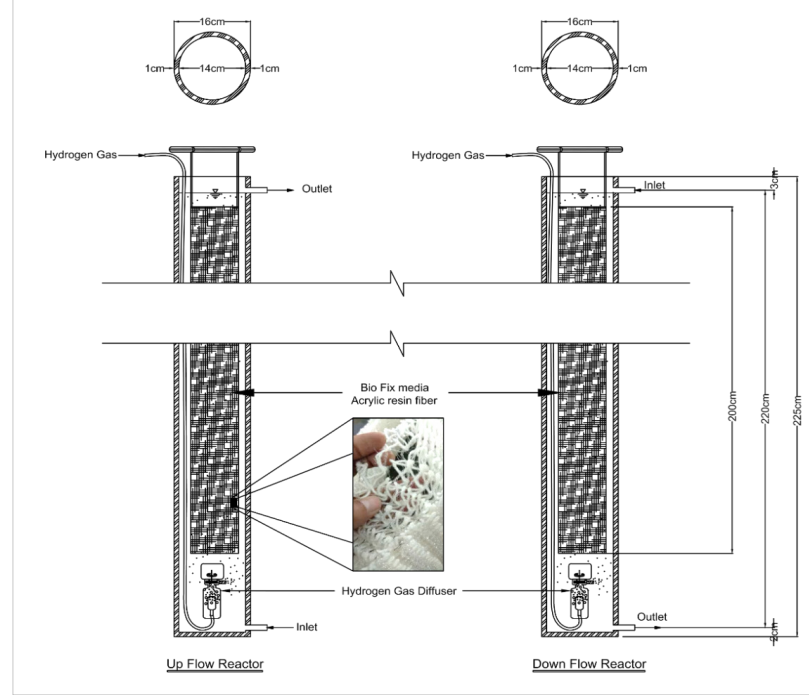




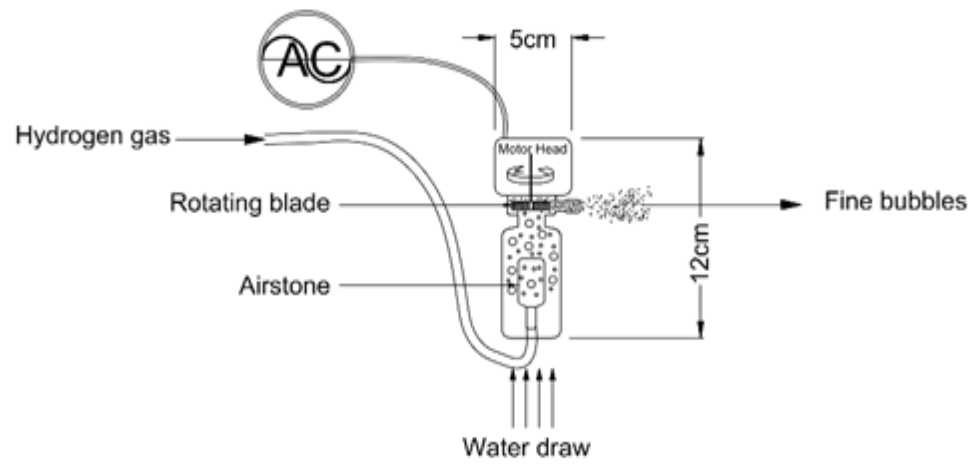

(a) Scale drawing of hydrogenotrophic denitrification reactors

(b) Combination of airstone and aquarium submersible pump for $\mathrm{H}_{2}$ gas diffusion

Fig. 1: Schematic diagram of HD reactors under study

Two reactors were different to each other only in position of inlet and outlets. Up Flow reactor has inlet at bottom and outlet at top and vice versa for Down Flow reactor. The bacteria were grown in Bio Fix media $(200 \mathrm{~cm} \times 10 \mathrm{~cm})$ suspended vertically in each reactor. $\mathrm{H}_{2}$ gas was subjected in the reactor from the $\mathrm{H}_{2}$ gas generators via a combination of airstone and aquarium submersible pump (BOYU SP-100A) for effective distribution of $\mathrm{H}_{2}$ gas.

Table 1: Summary of changes adopted during study

\begin{tabular}{|c|c|}
\hline Duration & Parameters \\
\hline $15^{\text {th }}$ day & Started reactor at $2.97 \mathrm{hrs} \mathrm{HRT}$ (flow rate of $190 \mathrm{ml} / \mathrm{min}$ ) \\
\hline $23^{\text {rd }}$ day & Shifted to $5.13 \mathrm{hrs}$ HRT due to poor performance (flow rate of $110 \mathrm{ml} / \mathrm{min}$ ) \\
\hline $32^{\text {nd }}$ day & Addition of $\mathrm{HCO}_{3}$ as IC source for Bacteria \\
\hline $58^{\text {th }}$ day & $\mathrm{H}_{2}$ gas dose was doubled with addition of reactor \\
\hline $60^{\text {th }}$ day & Flow rate was limited to $50 \mathrm{ml} / \mathrm{min}$ for ratio $\mathrm{Q}_{\mathrm{H}} / \mathrm{Q}_{\mathrm{w}}$ near to $2(11.29 \mathrm{hrs} \mathrm{HRT})$ \\
\hline $70^{\text {th }}$ day & IC dose was increased to meet $\mathrm{HCO}_{3}$ conc $^{\mathrm{n}}$ greater than $1000 \mathrm{ppm}$ \\
\hline
\end{tabular}

\subsection{Laboratory Analysis Methods}

Temperature, $\mathrm{pH}$ and DO tests were done in site for ease with Standard $\mathrm{pH}$ Meter [Lutron $\mathrm{pH}$ 223 (Range: 0-14)] and DO Meter [ID-150, (Oxyeye) Iijima Electronics Corp.] respectively and the collected samples were stored in $4{ }^{\circ} \mathrm{C}$ and were analyzed within a week of collection. $\mathrm{NH}_{4}-\mathrm{N}$ was analyzed by Phenate Method, $\mathrm{NO}_{2}-\mathrm{N}$ by Colorimetric Method, $\mathrm{NO}_{3}-\mathrm{N}$ by Ultraviolet Spectrophotometric Screening Method and bicarbonate by Titration Method. TOC was analysed with the help of TOC- UVA, [TOC analyzer (Kiritsu Chemical-Check Lab)].

\section{Results and Discussions}

As the two reactors were compared for the flow directions only, other parameters were kept constant in both reactors. The $\mathrm{pH}$ of the influent was near to 6.5 to 7.5 in the inlet whereas outlet yields higher $\mathrm{pH}$ from 8.5 to 9.5 . The influent $\mathrm{DO}$ after nitrification process was ranging from 3 to $5 \mathrm{mg} / \mathrm{l}$ and both anaerobic HD reactors were maintained DO less than $0.3 \mathrm{mg} / 1$. The temperature of water was maintained between 25 to $35^{\circ} \mathrm{C}$ during study and differences in two reactors were 
just within $\pm 2^{\circ} \mathrm{C}$. Bicarbonate within the ground water was consumed in nitrification process. So, the inorganic carbon source near to $45 \mathrm{mg} / 1$ which was insufficient for the HD reactors. Hence, an additional carbon source was introduces in $32^{\text {th }}$ day in form of sodium bicarbonate and kept $\mathrm{HCO}_{3}$ concentration above $500 \mathrm{ppm}$ as per Eamrat [2] and from that point the denitrification process accelerated and later changed to greater than $1000 \mathrm{ppm}$ as suggested by Ghafari as optimized dose [3].

Similarly, the ground water contains negligible amount of organic carbon. So, the total organic carbon was less than $3 \mathrm{mg} / \mathrm{l}$ for influent and effluent of both reactors. $\mathrm{NH}_{4}-\mathrm{N}$ in the influent is generally kept less than $10 \mathrm{mg} / \mathrm{l}$ by nitrification process and fluctuates time to time. As ammonia did not affected by the denitrification process, no significant changes in outlet were found. The Nitrate- $\mathrm{N}$ is in the influent is higher ranging from $80-100 \mathrm{mg} / \mathrm{l}$ during study. Nitrate was converted to nitrite. So, the concentration of $\mathrm{NO}_{3}-\mathrm{N}$ decreased and found minimum of 1.13 and $0.0 \mathrm{mg} / \mathrm{l}$ for Up Flow and Down Flow reactors respectively. The Nitrite-N is an unstable intermediate product in denitrification. However, this study had encountered the unprecedented amount of $\mathrm{NO}_{2}$ accumulation in water suggesting slower and inefficient conversion of $\mathrm{NO}_{2}$ in water. The concentration of $\mathrm{NO}_{2}-\mathrm{N}$ in inlet was generally below $5 \mathrm{mg} / \mathrm{l}$, but the concentration in outlet is higher with maximum of 78.89 and $72.55 \mathrm{mg} / \mathrm{l}$ for Down Flow and Up Flow reactor respectively.

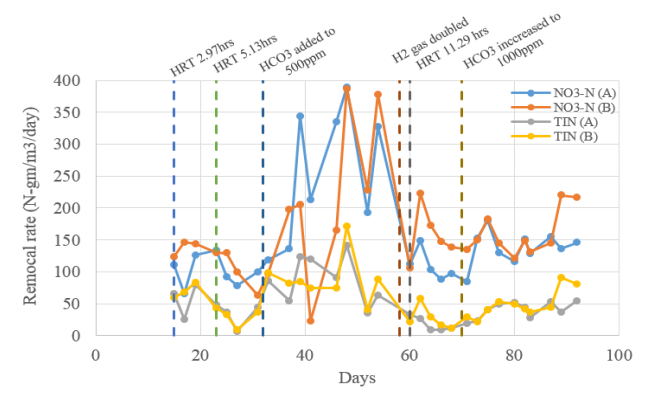

(a) Nitrogen removal rate in quantities per day

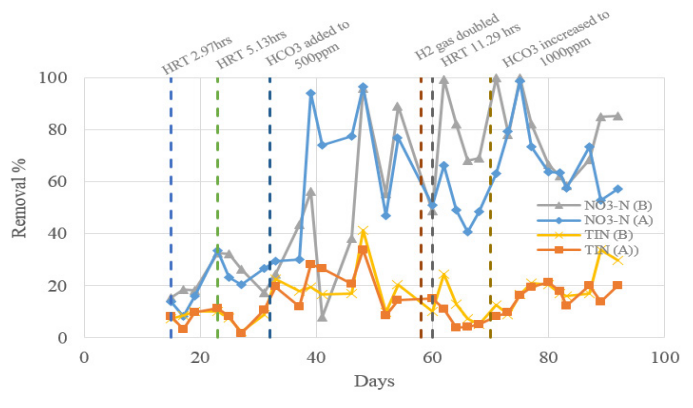

(b) Nitrogen removal efficiencies in percentage

Fig. 2: Performance of $\mathrm{HD}$ reactors

From Fig. 2, the $\mathrm{NO}_{3}-\mathrm{N}$ conversion reached highest sum of 389.31 and $387.37 \mathrm{~N}-\mathrm{gm} / \mathrm{m}^{3} / \mathrm{d}$ and also total nitrogen removal was 141.56 and $171.72 \mathrm{~N}-\mathrm{gm} / \mathrm{m}^{3} / \mathrm{d}$ for Up Flow and Down Flow reactors respectively on 48th day. Generally, the conversion pattern of nitrate is higher than that of nitrogen removal, suggestion the incomplete denitrification and has their difference equivalent to the amount to nitrite accumulated in water.

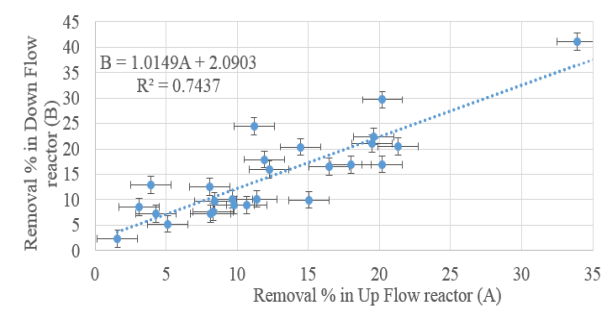

(a) Comparison in $\mathrm{NO}_{3}-\mathrm{N}$ removal

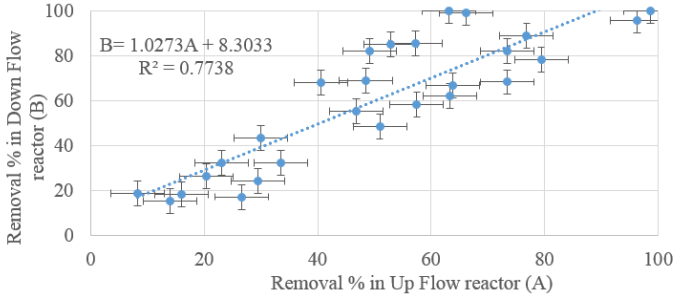

(b) Comparison in TIN removal

Fig. 3: Comparison between Up Flow and Down Flow performances 
The efficiencies also show the similar patterns. Nitrate conversion efficiency for Down Flow in $48^{\text {th }}, 62^{\text {nd }}, 71^{\text {st }}$ and $75^{\text {th }}$ days were $95.81,99.10,100$ and $100 \%$ respectively as the highest of all and also Up Flow reached to $93.92,96.29$ and $98.65 \%$ for the $39^{\text {th }}, 48^{\text {th }}$, and $75^{\text {th }}$ day respectively as its highest. But the total inorganic nitrogen removal was lesser than nitrate conversion and had highest of $33.89 \%$ in $48^{\text {th }}$ day for Up Flow reactor whereas for Down Flow 33.71 and $41.11 \%$ in $89^{\text {th }}$ and $48^{\text {th }}$ day respectively. The Average removal percent for $\mathrm{NO}_{3}-\mathrm{N}$ was 53.48 and $57.42 \%$ from Up Flow and Down Flow reactor respectively whereas TIN removal percent was an average of 13.86 and 15.74\% from Up Flow and Down Flow reactor respectively. From Fig. 3, we can directly compare between the performances of HD reactors in Up Flow versus Down Flow reactors. The Fig. 3 (a) gave the equation of the trend line which justifies the Down Flow is better than Up Flow in terms of nitrate conversion similarly, Fig. 3 (b) gave a trend line to justify the Down Flow found better than the Up Flow in total nitrogen removal.

\section{Conclusions}

As the study showed denitrification reaction in the studied reactor was incomplete and had only partial total nitrogen removal. This results in the accumulation of nitrite in the water. This unusual accumulation has led to the poor efficiency of the total nitrogen removal than the better performing nitrate conversion efficiencies for both Up Flow and Down Flow reactors. This may be due to the lesser contact time due to short circuiting phenomenon. Apart from this, the study has justified the better performance of the Down Flow reactor than Up Flow reactor in both case to nitrate conversion and total inorganic nitrogen removal. Even though the differences in two reactors seem small and insignificant, it will make a difference in larger scale like in treatment plants. Hence the optimization of HD reactor can be done in same reactor just by changing the flow direction.

Acknowledgement: The authors are grateful to the MSc in Environmental Engineering Program, Pulchowk Campus, IOE, TU, Nepal, SATREPS Program of JICA and University of Yamanashi, Kofu, Japan for providing the part of the plants and equipment support for this study.

\section{References}

[1] Chapagain SK and Kazama F (2012), Overview of Chemical Quality of Groundwaterin the Kathmandu Valley. In S. Shrestha, D. Pradhananga, V. Pandey, S. Shrestha, D. Pradhananga, \& V. P. Pande (Eds.), Kathmandu Valley Groundwater Outlook (p. 14 and 51), Kathmandu: Asian Institute of Technology (AIT), Thailand, The Small Earth Nepal (SEN), Nepal, Nepal Center of Research for Environment Energy and Water (CREEW), Nepal, Nepal International Research Center for River Basin Environment-University of Yamanashi, Japan.

[2] Eamrat R, Tsutsumi Y, Kamei T, Khanichaidecha W, Tanakad Y and Kazama, (2017), Optimization of Hydrogenotrophic Denitrification Behavior Using Continuous and Intermittent Hydrogen Gas Supply, Journal of Water and Environment Technology, 15(2): 15- 65.

[3] Ghafari S, Hasan M and Aroua MK (2009), Improvement of autohydrogenotrophic nitrite reduction rate through optimization of $\mathrm{pH}$ and sodium bicarbonate dose in batch experiments, Journal of Bioscience and Bioengineering, 107(3): 275-280.

[4] Hwang JH (2010, February 9), Two Stage Membrane Biofilm Reactors for Nitrification and Hydrogenotrophic Denitrification(Doctoral dissertation), Retrieved 02 14, 2018, from University of Minitoba: https://mspace.lib.umanitoba.ca/handle/1993/3870

[5] Kang KM, Kang YN, Choi IB, Gu Y, Kawamura T, Toyoda Y and Nakao A (2011), Effects of drinking hydrogen-rich water on the quality of life of patients treated with radiotherapy for liver tumors, Medical Gas Research, 1(1), p.11. 